\title{
Hovedværker om den kolde krig
}

Mette Skak

\section{Den for alvor interesserede i den kolde krig og den danske side af sagen gør klogt i at anskaffe begge disse hovedværker. Skal man vælge, bør det være Rosenfeldts}

John T. Lauridsen et al. Den kolde krig og Danmark. Gads leksikon. Gads forlag, 2011, 768 s.

Niels Erik Rosenfeldt: Verdensrevolutionens generalstab. Komintern og det hemmelige apparat. Gads forlag, 2011. $432 \mathrm{~s}$.

Danske historikere forsker for de flestes vedkommende i Danmarkshistorien. Ja, hvem ellers? Vi kan da ikke forvente at udenlandske historikere vil bruge tid på det. Så enkelt er det måske. Men når emnet vitterlig er internationalt - som nu den kolde krig - er provinsialismen yderst problematisk. Politikerne fra såvel højre som venstre fløj har deres store medansvar for at låse historieforskningen fast i nationalt snæversyn. De har bevilget så den ene, så den anden kulegravning af den kolde krig i Danmark. Den kommercielle krone på dette værk er Gads leksikon. Lad det være sagt med det samme, at det er et tungt og lærd værk, som bestemt er værd at læse.

Den kolde krig udgjorde sidste halvdel af det tyvende århundrede, som den britiske venstrefløjshistoriker Eric Hobsbawn kalder for The Age of Extremes. Den kolde krigs altafgørende ekstremisme - leninismen - får læseren imidlertid uendelig lidt at vide om, fordi synsvinklen er Danmark. Danmark blev - måske på et hængende hår - sikret en stilfærdig og hyggelig kold krig under den amerikanske atomparaply som medlem af NATO. Følgelig er der en ti sider lang og i sig selv læseværdig artikel om NATO, mens Warszawapagten spises af med godt to, ganske vist oplysende sider. 
Men Warszawapagten blev først oprettet i 1955, og da der intet opslag er om Sovjetunionen som trussel fra dag et, blot en artikel om Danmarks forhold til Sovjetunionen forfattet af en ekspert på forholdet mellem Danmark og USA, lades læseren - ikke mindst den unge læser uden forhåndsviden - fuldstændig $\mathrm{i}$ stikken. Der går kort sagt Yankie Bar (s. 80) i emnet den kolde krig, fordi der hertillands forskes i metermål i amerikanisering.

Derimod leder man forgæves efter opslagsordet sovjetisering; Lenins ord for hvad verdensrevolutionen gjaldt, og som derfor principielt også var hans tro følgesvend Stalins dagsorden for Danmark. Artiklen 'Sovjetunionen, Danmarks forhold til' får slet ikke konkretiseret, at det formentlig var på et hængende hår, at Danmark ikke fik samme skæbne som den østlige halvdel af Europa besættelsen af Bornholm nævnes blot.

Det måske afgørende drama lå i de allierede troppers indbyrdes slutspil under nedkæmpelsen af Tyskland i maj 1945, hvor den sovjetiske feltmarskal Rokossovskij (ham er der intet opslag om) lå med sine styrker ved Lübeck og var klar til at rykke nordpå og erobre Jylland. Kun det forhold, at Montgomery fik nys om sagen og besluttede at overflødiggøre denne fremrykning med sine kontra-troppebevægelser, fik kvalt det militære tilløb til en politisk sovjetisering af Danmark.

\section{Enhedsforhandlingerne}

Et andet afgørende drama var enhedsforhandlingerne mellem DKP og Socialdemokratiet; en sag, der førhen optog forskerne, men som her ikke værdiges et selvstændigt opslag - stoffet gemmer sig i artiklen om Danmarks Kommunistiske Parti, altså DKP. Her står der lakonisk: "Forhandlinger med Socialdemokratiet om sammenlægning brød dog sammen i sommeren 1945" - uden at nævne, at det skyldes stærke socialdemokratiske antikommunister som Hans Hedtofts vilje til at styre fri af kommunisternes omklamring.

Ellers kunne det være gået som i det østlige Tyskland, hvor socialdemokratiet aldeles ufrivilligt blev opslugt af kommunisterne under Komintern-veteranen Walter Ulbrichts ledelse. Helt i tråd med Stalins bedrageriske folkefront-linje sagde han i maj 1945: "Es muss demokratisch aussehen, aber wir müssen alles in der Hand haben". DKP-artiklen omtaler med rette SED (Sozialistische Einheitspartei Deutschlands) som det $\varnothing$ sttyske kommunistparti, for det var realiteten.

Med andre ord snyder man læseren for afgørende indsigt i 'enhedsforhandlingerne' som magtovertagelse under dække af antifascistisk enhed, patriotisme osv. ved at gøre sammenslutningsforhandlingerne til en parentes i DKP's historie. For selv om DKP ikke havde held til at snigløbe den danske demokratiske styre- 


\section{LITTERATUR}

form, var og blev partiet en realpolitisk trussel. DKP-artiklen indeholder ingen krydshenvisninger til fx Morten Møllers artikel om Mogens Fog. Den kunne ellers have bragt læseren lidt på sporet af det drama, der udspillede sig bag kulisserne ved befrielsen i 1945, om Danmarks storpolitiske skæbne.

Møller står bag en meget rost biografi om Fog med lange, saftige citater, der dokumenterer Fogs mummespil med sit DKP-ståsted. Møller påpeger, at Fog fra foråret 1943 dvs. samtidig med Kominterns formelle nedlæggelse; mit indskud var "uformel leder af den tværpolitiske, men kommunistisk ledede modstandsorganisation Frit Danmark" samt at han blev en hovedaktør i Frihedsrådet og senere minister for særlige anliggender. Møller fortsætter: "Fog havde under modstandskampen nedtonet sin kommunistiske holdning for at fremme DKP's ønsker om en tværpolitisk folkefront". Fogs kontakter til Komintern og hans høje anseelse i Moskva gør, at man roligt kan tolke dette som aftalt spil på linje med Kominterns $\varnothing v-$ rige fjernstyring af kommunisterne andre steder. Den ophørte ikke med Kominterns formelle nedlæggelse i 1943, som Stalin gerne ville forlede folk til at tro.

\section{Skævvridning}

Men redaktørerne bag Gads leksikon om den kolde krig har end ikke svunget sig op til at bringe en artikel om Komintern, kun en om det anderledes bovlamme Kominform, som man allernådigst har overladt til den russiskkyndige sovjetolog og historiker Erik Bach Nielsen. Her kan man sige, at ikke bare provinsialismen, men også mainstream-periodiseringen af den kolde krig spøger som skæwridning af værket. Den indledende oversigtsartikel gør den kolde krig til noget, der begyndte i 1945, nærmere betegnet 1947. Det baner vejen for, at den sovjetiske kolde krig såsom oprettelsen af Kominform kan beskrives som svar på Marshall-hjælpen og Trumandoktrinen. Underforståt: det er USA, der har hovedansvaret for den kolde krig; Sovjetunionen var reaktiv og gav blot igen med samme mønt. Sagen er nemlig, som opslaget om Kominform viser, at af og til føler redaktørerne det nødvendigt at forlade det provinsielle perspektiv og give os udvalgte glughuller til den verdensomspændende kolde krig. Godt for det, men udvalget af almene koldkrigs-opslag giver blot indblik i den nyere danske koldkrigsforskning og slet ikke den internationale forskning.

Der er fx intet opslag om Igor Gusenko og hans opsigtsvækkende afhopning til Canada i september 1945; noget, der ellers optog sindene jf. den danske bog Russisk spionage $i$ Canada fra 1947. Gusenko afslørede den omfattende sovjetiske spionage i USA og afslørede dermed 
Stalins dobbeltspil. Det gjorde ham afsindigt rasende, og hans hævn og paranoia var i grunden det, der udløste det kolde krig, hævdes det i et erindringsværk fra en ansat i GRU, den sovjetiske militære efterretningstjeneste. Selve GRU har værket her et opslag om, men ikke et om Venona, det program for afkodning af den sovjetiske spionage i USA, der var en stor sag i amerikansk koldkrigsforskning, fordi den sovjetiske spionageoffensiv viser, at ikke alt var McCarthyistisk hysteri.

McCarthyisme er der naturligvis en grundig artikel om, men den oplyser intet om, hvad der var hysteri og hvad der var virkelighed $-\mathrm{fx}$ at Rosenberg-ægteparret begge var sovjetiske spioner. Det er rigtigt, at McCarthy intet vidste og blot fantaserede om kommunistiske spioner, for på det tidspunkt, hvor han slap sin hetz løs, var jagten på de virkelige spioner - i modsætning til hans indbildte af slagsen - gået ind.

Den såkaldte anden kolde krig dækkes blandt andet ind via opslag om fx dobbeltbeslutningen samt Able Archer, NATO-øvelsen fra 1983, som her fremstilles som om Sovjetunionen for alvor blev opskræmt, samt at Reagans erkendelse heraf blev et vendepunkt i den kolde krig. Den ansete amerikanske koldkrigsforsker Mark Kramer, gæsteprofessor på Aarhus Universitet i 2008, har imidlertid sandsynliggjort, at Able Archer blev gjort til en stor sag af Sovjetunionen uden at være det. Hans forskning i den sovjetiskøsteuropæiske oprustning omkring 1951 torpederer myten om fraværet af en sovjetisk militær trussel i form af et uprovokeret angreb (ss. 597598; se dertil min artikel i Udenrigs vol. 64, nr. 1, 2009, ss. 56-64).

I overordnet perspektiv er det fatalt, at dette koldkrigsværk gør sig blind for, at Sovjetunionen var en hypermilitaristisk økonomi, der hvilede på en blanding af politiske og militære angrebsplaner mod Vesten. Det har den polsk-tyske forsker Bogdan Musil forsket indgående i. Opslaget 'rustningsindustri' handler helt latterligt om det danske fnug af en rustningsindustri, hvorimod vi ved fra russiske rustningsøkonomer med insiderviden fra en fortid i GRU, at Sovjetunionen var ét stort militærindustrielt kompleks. Rustningsbyrden var ' 100 pct. af BNP' som Vitalij Sljykov har udtalt i en samtale med mig.

Som det er fremgået af min kritik er det mindst lige så fatalt, at værket i virkeligheden er blindt for leninismen som politisk-ideologisk trussel. Herom kan man læse George F. Kennans klassiske X-artikel fra 1947, som man passende kunne have oversat til dansk og bragt under bogstavet $\mathrm{X}$, der ikke er repræsenteret med noget opslag. Derimod omtales Cubakrisen, hvor der dvæles ved den danske vinkel, hvorimod det forbigås, at Fidel Castro ville have Khrusjtjov til at trykke på knappen til raketterne og ikke bøje af. 


\section{LITTERATUR}

\section{Postrevisionistisk tilgang}

Der er lange og sjove artikler om tegneserier samt om udviklingsbistand og velfærdsstaten - knap så sjove, men faktuelle. Der er gode, relevante artikler om såvel Blekingegadebanden som venstreradikale grupper og rene pudsigheder som opslaget om Hans-Jørgen Lembourn. Der er nemlig intet opslag om den sovjetiske nobelpristager Aleksandr Solsjenitsyn, der med al respekt var den, der gjorde Lembourn berømt - som vært for Solsjenitsyn, hvis værker åbnede omverdenens øjne for de sovjetiske koncentrationslejre Gulag-øhavet. Men Gulag er der heller ikke er noget opslag om. Ja, vi får sandelig ikke meget at vide om den kolde krigs ekstremisme østpå - for opslaget om Kina handler nemlig kun om Danmark og Kina.

Alligevel ville man være et skarn, hvis man ikke tilkendte Gads koldkrigsleksikon blivende værdi som en opdateret dansk efterkrigshistorie garneret med udvalgt almendannelse om den kolde krig. Værket er en milepæl som udtryk for den postrevisionisme, der samlet set kendetegner den nyere danske koldkrigshistorie. Postrevisionismen er en tilgang, der af frygt for ikke at blive tendentiøs alligevel ender med at blive det. Det lyder kryptisk, så det må forklares nærmere.

Postrevisionismen er de senere årtiers forsøg på et formulere en gyl- den middelvej mellem venstrefløjens åbenlyst uholdbare revisionisme og højrefløjens politisk forkætrede traditionalisme (også kaldet ortodoksi). Sidstnævnte lagde skylden for den kolde krig på Sovjetunionen med dens iboende ekspansionstrang og aggressive ideologi, dvs. leninismen, hvorimod revisionismen lagde skylden på USA og dets skjulte dagsordener. Blandt redaktørerne placeres Poul Villaume i dette opslagsværk i feltet mellem (udogmatisk) revisionisme og postrevisionisme, hvorimod bidragydere som traditionalisten Bent Jensen korrigerer helheden i retning af den midtsøgende postrevisionisme.

Det, der er selve postrevisionismens svaghed, er dens underliggende ubehag ved at tage klar stilling i spørgsmålet om ansvar i den kolde krig. Den gør det med kliniske betragtninger om, at skyldsspørgsmålet er irrelevant. For ifølge postrevisionismen havde ØstVest-konflikten rod i det såkaldte sikkerhedsdilemma, dvs. den iboende usikkerhed mellem stater pga. mangel på information om hinandens hensigter.

Begrebet sikkerhedsdilemma bringes på bane af Villaume i hans indledende overordnede analyse af den kolde krig s. 28. Ligeledes bruger han postrevisionismens signalord struktur ("Den kolde krig må forstås som en stor historisk struktur", s. 11) samt metaforer som koldkrigsspiralen (s. 15). Ikke desto mindre har Robert Jervis - den politolog, 
der for alvor har bragt sikkerhedsdilemmaet ind i den almene sikkerhedspolitiske litteratur - lagt afstand til sikkerhedsdilemmaet som nøgleargument. Det sker i artiklen 'Was the Cold War a Security Dilemma?', trykt i Journal of Cold War Studies, (2001). vol. 3, no. 1, winter, pp. 3660 . Pointen hos Jervis er, at forestillingen om symmetri mellem parterne ikke holder. Sovjetunionen var aldrig nogen status quo-magt og stræbte ikke efter sikkerhed i gængs og opnåelig forstand modsat USA.

\section{Ikke en systemkonflikt}

Postrevisionismen for ikke sige revisionismen kommer til udtryk $i$, at Villaume gør den kolde krig til "en systemkonflikt mellem et kapitalistisk, kolonialistisk og demokratisk Vesten og et planøkonomisk, diktatorisk og totalitært Øst” (s. 15). Umiddelbart lyder det sobert og balanceret, men det er en vildledende balance. Det østlige synderegister med diktatur og totalitarisme søges i Villaumes formulering opvejet af Vestens koloniale synderegister. Vestlig kolonialisme behandles via opslagene 'afkolonisering og kolonisering', Algierkrigen samt Vietnamkrigen.

Til gengæld leder man forgæves efter de baltiske skovbrødres guerillakrig mod den sovjetiske overmagt samt ukrainernes, hviderussernes, polakkernes væbnede modstand for ikke at tale om general Vlasovs Russiske Befrielseshær ROA. ROA omta- les ret åbent og ærligt i Rusland i dag. Så i praksis lastes Sovjetunionen ikke for sin kolonialisme og imperialisme, selv om Villaume s. 15 omtaler de russiske historikere Subok og Pleshakovs tese om det revolutionær-imperiale Sovjetunionen. Som der ovenfor er givet eksempler på, er stofvalget og til tider indholdet i de enkelte opslag tendentiøst navnlig i sine fravalg.

Den kolde krig var ikke nogen klinisk, symmetrisk systemkonflikt. Den var ligesom Anden Verdenskrig et eksistentielt opgør mellem diktatur og demokrati - hvor Sovjetunionen altid repræsenterede proletariatets diktatur under dække af folkedemokrati, antifascisme, fred og andre til lejligheden opfundne plusord. Koldkrigen var med Samuel Huntingtons begreb et clash of civilizations, et sammenstød mellem retsstaten og slyngelstaten eller udtrykt med lidt mere lokalkolorit: et sammenstød mellem den retskafne nordiske velfærdsstat og det røde byzantinske nomenklaturavælde. Det vidste de nordiske socialdemokrater; derfor havde de et intenst antikommunistisk samarbejde, som Johnny Laursen glimrende beskriver i artiklen om nordisk efterretningssamarbejde.

\section{Verdensrevolutionens generalstab}

Det andet og reelt mere fyldestgørende værk om den kolde krig, der her skal anmeldes, er Niels Erik Ro- 


\section{LITTERATUR}

senfeldts bog Verdensrevolutionens generalstab. Komintern og det hemmelige apparat. Ganske vist indgår den kolde krig ikke i titlen og er heller ikke den egentlige genstand for analysen. Men alligevel mener jeg, at denne monografi bidrager væsentligt til folkeoplysningen om den kolde krig på en måde, som Gads leksikon slet ikke gør.

Rosenfeldts speciale som historiker har internationalt format; han har skrevet disputats om de dunkle og konspiratoriske grene og rutiner i Stalins magtapparat. Han skal have megen tak for i denne bog at have helliget sig formidlingen af sin uhyre viden om organisationen Komintern som den side af apparatet, der havde direkte brod mod omverdenen og dermed også mod det danske politiske system. Komintern anså sig selv for at være verdensrevolutionens generalstab, dvs. en verdensomspændende Blekingegadebande med forgreninger og forbindelseslinjer overalt på kloden, herunder en overgang et vigtigt kontor i København.

Analysen følger to parallelle spor, dels analyseres Kominternapparatets udvikling, dels kobles dette bureaukratiske stof sammen med analyser af Kominterns hegemoniske partilinje på vegne af alverdens kommunistpartier kaldet sektioner samt den overordnede internationale udvikling, som Komintern søgte at udnytte. Indimellem er der blevet plads til sideblikke på den danske og den øvrige skandinaviske kommunisme, som Rosenfeldt skriver.

Denne klart sekundære vægtning af det nationale danske og nordiske stof er helt igennem forsvarlig, eftersom det fine ved bogen herved bliver dens konsekvente placering af DKP's samt enkelte kommunisters og sympatisørers gøren og laden i den overordnede sammenhæng, hvor stoffet hører hjemme. Denne bog får således fortalt, hvad der var på spil i den kolde krig - nemlig om muligt at gribe magten eller i hvert fald at presse de kapitalistiske demokratiers samfundsudvikling og sikkerhedspolitik i den retning, Sovjetunionen ønskede. For det stod fra starten klart, at det var Kreml, der havde magten over Komintern, ikke omvendt. De berygtede 21 optagelsesbetingelser fra 1920 var Lenins påhit som middel til at sikre jernhård disciplin og hensynsløshed, herunder viljen til at bruge ulovlige metoder, ja om nødvendigt terror.

Stalins 'forfinelse' af Lenin gik ud på endnu mere konsekvent at gøre Komintern til de sovjetiske efterretningstjenesters forlængede arm samt at ophøre med at indkalde organisationen til verdenskongres, da først den bedrageriske folkefrontslinje var lagt i 1935 i samråd med Kominterns nye leder, bulgareren Georgi Dimitrov.

Mange tolker dette skridt som bevis for, at Stalin hellere ville opbygge 'socialisme i ét land', nemlig Sovjetunionen, og lægge verdensrevolutio- 
nen på hylden - det er fx den tolkning PET-kommissionen anlægger, påpeger Rosenfeldt s. 143. Men hans egen analyse peger på, at Stalin snarere havde set det smarte $i$ at kombinere mellemkrigstidens nødvendige kamp mod fascismen med kampen om magten selv i de ikke-fascistiske lande. Stalins ordrer lød følgelig på at nedtone leninismen og proletariatets diktatur til fordel for patriotisme under slagordet 'nationale fronter' parallelt med, at Komintern blev nedlagt (s. 364). Sovjetunionen selv ophørte i maj 1943 med at bruge Internationale som nationalsang, og Stalin gav den russisk-ortodokse kirke friere tøjler senere samme år; et sammenfald, som amerikanske koldkrigsforskere har gjort mig opmærksom på.

\section{Ny viden}

Rosenfeldt fornyer vor viden om Komintern ved at pege på mindre kendte aktører såsom bolsjevik-veteranen Jelena Stasova - foto s. 87. Hun var en typisk Komintern-apparatjik, der delte sin tid mellem at hjælpe det tyske kommunistparti med at organisere dets hemmelige arbejde i 1920'erne og senere at opbygge Stalins lige så hemmelige informationsapparat.

Det er dette Komintern-perspektiv, som bogen anlægger på sin udredning af den danske kommunist Arne Munch-Petersens skæbne. Han var kurer for det såkaldte OMS, som igen var det hemmelige nervecenter i Komintern og helt penetreret af det sovjetiske hemmelige politi. Da Stalins terror ramte Komintern, gik det ikke mindst ud over OMS'erne, fordi det var OMS, der forfalskede pas og sendte kodede meddelelser, Komintern-agenter, penge samt våben ud i verden og indkaldte folk til fremmøde i Moskva. Derfor er det pikant, at det var OMS, der i dybeste hemmelighed havde kontor i København i 1930'erne.

Rosenfeldt peger s. 141 ff. på en anden interessant OMS-agent, den danskfødte Georg Laursen, der skiftede efternavn til Moltke, men som ikke må forveksles med Kai Moltke, der også havde sin gang i Kominterns korridorer i mellemkrigstiden. Georg Laursen/Moltke arbejdede for den sovjetiske militære efterretningstjeneste i Kina i 1930'erne og kom fra omkring 1940 til at lede kontoret for Skandinavien i Kominterns hemmelige kadreapparat. Som bekendt lød Stalins tvetydige motto: "kadrerne afgør alt"; ergo bør det ikke overraske, at Georg Laursen/ Moltke fortsatte opad i sin sovjetiske karriere som Radio Moskvas danske stemme under Anden Verdenskrig under dæknavnet Peter Hansen. Senere sad han i SUKPs centrale apparat og øvede årelang indflydelse på den sovjetiske Norden-politik.

Rosenfeldt giver smagsprøver på Laursen/Moltkes svingen pisken over DKP'erne hjemme i Danmark på vegne af Moskva s. 319 og viser 


\section{LITTERATUR}

Laursen/Moltkes insiderviden om Alvilda Larsens konspirative arbejde i Sverige i 1943. Da Hitler angreb Sovjetunionen i 1941 evakueredes hele Komintern-apparatet til Ufa, hovedstaden i Basjkirien, og 'Peter Hansen' alias Laursen/Moltke fulgte med som ansat i udlandsinformationstjenesten med det sære navn Institut nr. 205.

\section{De hemmelige systemer}

Kominterns såkaldte nedlæggelse $\mathrm{i}$ maj 1943 var nemlig en fugl Føniksnedlæggelse. Manøvren gik ud på at omdanne organisationen til en afdeling direkte underlagt SUKP's Centralkomite. I første omgang skete det under akronymet OMI, senere OVP med en anden kometkarriere, nemlig den allerede da - i Litauen berygtede Mikhail Suslov i spidsen. Fra 1948 fandt 'Komintern-overvågningen' af kommunisternes gøren og laden sted under betegnelsen OVS. Efter Stalins død genopstod Komintern som SUKP's berømte Internationale Afdeling, som i årene 1954-1986 blev ledet af Kominternbossen Dimitrovs særlige håndlanger Boris Ponomarjov. Suslov og Ponomarjov var hyppige samtalepartnere for DKP's ledelse, til tider danske ministre under hele den kolde krig. De overlevede begge såvel Stalins som Khrusjtjovs og Bresjnevs luner som generalsekretærer og havde megen magt som chefideologerne bag SUKP's politik heriblandt inva- sionen i Afghanistan og krigsretstilstanden i Polen.

De hemmelige systemer for kanalisering af partistøtte til DKP og andre - jeg vil tillade mig at kalde dem sådan - sektioner af SUKP fortsatte overraskende gnidningsløst trods Anden Verdenskrig og den formelle opløsning af Komintern. Det er fremgår af antologien Morten Thing (red.), Guldet fra Moskva fra 2001, der bygger på det såkaldte Fond-89-kildemateriale. Ud over det nævnte Institut nr. 205 fortsatte Komintern uanfægtet sin holdningsbearbejdelse af tyske og andre krigsfanger efter Kominterns formelle opløsning inden for rammerne af det såkaldte Institut nr. 99. Instituttet havde den senere østtyske partichef Ulbricht i en hovedrolle - Rosenfeldts bog har et sigende foto af ham i selskab med krigsfanger s. 337. Institut nr. 99 har fx tyskeren Jörg Morré forsket indgående i, ligesom det indirekte beskrives i Wolfgang Leonharts erindringer.

Det mest interessante er imidlertid Institut nr. 100, det oprindelige OMS-apparats efterfølger, der fremdeles blev ledet af den sovjetiske efterretningsofficer Ivan Morosov (s. 366). Under Anden Verdenskrig og flere år efter stod Institut nr. 100 for pengeoverførsler, våbenleverancer og hemmelig radiokommunikation (sammen med Institut nr. 205) med partisaner i det tyskbesatte Europa. Det ved vi fra russiske Kominterneksperter som Grant Adibekov og 
Natalja Lebedeva. Deres pointe om Kominterns forøgede styrke og betydning efter den formelle nedlaggelse kan i den grad underbygges gennem de aflytninger, som den britiske efterretningstjeneste foretog i krigens sidste år og et par år efter under kodenavnet ISCOT. ISCOT-programmets rådata - de kodede meddelelser mellem Moskva-centret og kommunistiske baser rundt omkring i Europa og i mindre grad Nordøstasien - svandt imidlertid pludselig ind. Det skyldes muligvis, at den berømte spion Kim Philby opdagede aflytningen og beslutsomt afslørede den for sine sovjetiske arbejdsgivere.

ISCOT ophørte næppe, fordi der ikke var mere at komme efter! Rosenfeldt kender tilsyneladende ikke til de enestående ISCOT-kilder, men under alle omstændigheder har han fuld rygdækning, når han s. 367 bebrejder PET-kommissionen dens naive analyse af forbindelseslinjerne mellem DKP og Moskva under og efter Anden Verdenskrig.

For selv om det ikke lykkedes at sovjetisere Danmark eller andre lande i Vesteuropa i 1940'erne var de sovjetiske forsøg herpå hverken halvhjertede eller amatøragtige. Man spillede bevidst på den soft power, som den Røde Hær, kommunismen og Uncle Joe pludselig besad, og som nærved gjorde den konser- vative John Christmas Møller til en dansk Edvard Benes. Benes lagde som præsident i Tjekkoslovakiet ryg til de tjekkoslovakiske kommunisters salamitaktiske sovjetisering af landet forud for Pragkuppet i 1948; en magtovertagelse som Kominternspidser som Klement Gottwald stod bag.

Om Pragkuppet kan man desværre ikke læse i Gads koldkrigsleksikon, kun om Pragforåret; men man kan i det mindste læse om Christmas Møller under C, fx at han i maj 1945 chokerede alle ved at erklære: "vi er alle socialister".

Konklusion: den køber, der for alvor er interesseret i den kolde krig og de danske sider af sagen gør klogt i at anskaffe begge de anmeldte værker. Hver på deres måde er de hovedværker om den kolde krig. Problemet med Gads koldkrigsleksikon er, at det ikke kan stå alene. Så hvis man som køber er ramt af finanskrise og skal vælge, bør man måske styre uden om mainstream og bruge sine spareskillinger på Rosenfeldts bog. De er givet godt ud, for Rosenfeldt skriver godt og livligt om sit bizarre emne. Det kan man ikke altid sige om forfatterne i Gads Koldkrigsleksikon.

Mette Skak, lektor ph.d. på Institut for Statskundskab, Aarhus Universitet. 